\title{
Impact of Supplier Hubs on the Scottish Electronics Industry
}

\author{
A. S. Carrie and A. E. Reid \\ Department of Design, Manufacture and Engineering \\ Management, University of Strathclyde \\ 75 Montrose Street, Glasgow, G1 1XJ, Scotland, UK \\ Telephone +44 (0)1415482894 \\ $\mathrm{Fax}+44$ (0)1415520557 \\ a.s.carrie@strath.ac.uk
}

\begin{abstract}
In terms of the contribution to the Scottish economy, the electronics industry is by far the most valuable. Its value in 1996 was approximately $£ 10$ billion and accounted for more than half of Scotland's exports. Many of the companies are multi-national OEMs, who came to Scotland as inward investing companies. As the world environment in which the industry operates changes, the commitment of OEMs to their Scottish operations may not be secure, with a risk to employment by both OEMs and indigenous suppliers. A recent development is the creation of supplier hubs. To some extent, the advent of these businesses means a substantial change in the supply chain strategy of the OEMs. This paper discusses the impact these operations will have on the industry and on the economy.
\end{abstract}

\section{Keywords}

Electronics industry, supplier hubs, strategic impact 


\section{INTRODUCTION}

Today the Scottish electronics industry employs 40,000 people directly and a further 30,000 in the supply infrastructure. There are now more than 550 electronic manufacturing and supplier companies in 'Silicon Glen'. In terms of the contribution to the economy, electronics is by far the most valuable industry. Its value in 1996 was approximately £10billion and accounted for more than half of Scotland's exports. The major product groupings within the industry include:

- PCs, laptops and workstations

- Disk drives, cable harnessing

- Printers, keyboards and peripherals

- Semiconductor devices and PCBs

- TV, VCRs, CDs, stereos and other consumer electronics

- Cellular phones and telecommunications products

- ATMs and funds transfer systems

- Networking and security systems

- Navigation and sonar systems

- Microwave products

- Power supplies

- Software and compilers

Many of these companies are multi-national OEMs, who came to Scotland as inward investing companies. Early inward investing companies were from USA, followed by companies from Japan, and more recently from Taiwan and Korea. An important segment of the industry is involved in the manufacture of computers, including IBM, Compaq, Digital and Sun. In fact approximately $40 \%$ of the PCs sold in Europe are built in Scotland. With five of the world's top eight computer manufacturers locating a manufacturing base in Scotland there has been an attraction for foreign companies keen to provide service for these multinationals. In $1995 / 96$ the supply base output was worth $£ 1$.2billion in total with $£ 435$ miliion (35\%) being spent by the Scottish based OEMs.

\section{THREATS AND OPPORTUNITIES IN A CHANGING WORLD}

The dependence of Scotland's electronic industry on inward investment companies - $60 \%$ of output in 1994 - has created an industry that can be greatly affected by global competitive factors. Ten to fifteen years ago, Scottish economic development and government agencies together with the OEM companies worked hard to build up a supply industry capable of winning a substantial share of the OEMs' supply spend. This has been very successful. Relationships between suppliers and OEMs have moved gradually from component procurement to partnership sourcing with suppliers providing increased levels of service to OEMs, through collaboration in design and undertaking added value operations such as assembly operations to simple component production. 
However, over the years the industry has become much more competitive. One of the most significant changes has been the rise of outsourcing, so that many OEMs are now simply final assemblers, making very few of their components themselves. They source supplies not just from local suppliers, but now look for low cost supplies on a global basis. In these circumstances, the OEMs may be less committed to their operations in Scotland.

Thus, Scottish operations of both OEMs and suppliers are under threat. Indeed, a pessimistic scenario suggests that:

- There is a possibility of major plant closures with movement to Eastern Europe and Asia

- It will be difficult to attract new inward investment

- Scotland's position as a value added logistics gateway into Europe is eroding

- There is a general weakness in the cycle of innovation from inception of product ideas through to marketing and supply

To minimise these threats, Scottish industry must seek to:

- Improve the value add of its companies - both OEMs and suppliers - to provide differentiation from the other competing locations.

- Encourage the establishment of more design and developmental work as opposed to just manufacturing facilities making goods designed up in other countries. Only 6\% of employees in 1993 were employed in R\&D and these were mostly in defence companies.

- Reduce the reliance on hardware manufacturing (55\% of output in 1993 as against $16 \%$ in the global electronics market) by nurturing of the software industry ( $7 \%$ as against $44 \%$ globally).

- Support and develop the supply base to provide a world class service with emphasis on value add, performance, delivery and the ability for world-wide supply.

\section{THE EMERGENCE OF THE SUPPLIER HUB}

When OEMs are simply final assemblers, their own manufacturing operations become relatively less important and their supply chain logistics become much more important. Managing materials in such an industry as that of PC manufacture is not easy. There are a number of problems:

1. Inventory must be kept at a minimal level because of the high costs, space restrictions and risk of obsolescence within weeks.

2. Manufacturing requires the right materials at the right time, but demand can rapidly fluctuate.

3. It is too costly to use traditional approaches of buffer inventory to solve demand changes.

4. Failure to meet demand will quickly lose customers because of the competitiveness of the industry. 
The short life cycle of PC products and the high rate of new product introduction magnify these problems.

These factors have led to the rise of the "supplier hub". A supplier hub is a warehouse managed by a material supplier or independent group, sometimes known as a third party logistics provider, to which material is shipped for JIT calloff by the purchasing company. Instead of individual suppliers holding a great deal of inventory to satisfy the OEMs and performing JIT delivery runs several times a day, a hub company will manage the transportation, warehousing and supply.

The supplier hub can provide a variety of other services:

- it can be the single point of contact for the OEM apart from price negotiations and can have a view of stock, stock in transit and stock in production

- visibility of the supply chain including passing on of information to both suppliers and customers

- value adding activities, such as simple product customisation, board final configuration and country kits (keyboard, manual and cables which change with the nationality of the market)

- additional quality and subassembly work carried out at the hub for a supplier such as testing, quarantine, repair and repackaging

- customs management associated with imported goods and the paperwork that this involves

- monitoring of daily usage of components and refining of longer term forecasts

- 24 hours a day, seven days a week delivery.

Close relationships between all three - supplier, hub and customer - with the sharing of sales and forecasting data are crucial to the success of a hub operation. This requires advanced IT systems with the capability for EDI.

\section{IMPLICATIONS FOR THE SCOTTISH SUPPLY BASE}

At present, supplier hubs mostly deal with imported components and offer the OEM a way to get JIT delivery without having to manage the logistics of all the supplying companies. However, there are disadvantages for the suppliers. Costs are pushed onto the supplier, as it must pay for the vendor hub in most cases marginally offset by an increase in component price. In addition, these companies are not paid until the time of use on the production line. For smaller companies, this may result in cash flow difficulties. Increasingly, it is likely that if they cannot go through the hub, business will be lost. This could be dangerous for Scottish component manufacturers in that they may face additional competition from the Far East, since effectively they would lose their location advantage. In addition, the aim of many of these hub operations is to eventually move into assembly work for the OEM. This would bring them into competition with established contract assemblers. 
Furthermore, the emergence of the supplier hub represents a reversal of supply chain management strategy over the past decade or so. Price competition in the industry has become very strong and margins are tight, so global sourcing on a lowest price basis has become more common, with many sourcing decisions being taken centrally, usually at corporate headquarters. Instead of getting close to suppliers, OEMs may adopt a more remote attitude, dealing with the supplier hub, who may not be an indigenous company but may be itself an inward investing company, with close links to the OEM's corporate HQ operations where sourcing decisions are made.

\section{SURVEY OF INDUSTRY IN RELATION TO SUPPLIER HUBS}

The introduction of supplier hub operations into the Scottish electronics industry is still in its infancy, but could have major impact in the future. These impacts could be negative, making it more difficult for local suppliers to win a share of OEM spend, or positive, creating new business opportunities. To assess the future impacts a survey of a cross-section of the industry was conducted. A questionnaire was developed covering various aspects of production management, including the computer systems used to support operations, with two main sections one focussing the perspective of OEMs and the other adopting the perspective of suppliers. The study was carried out by personal interview with senior procurement executives, not by post since a deep understanding of opinions and attitudes was required not simple facts. The survey included 4 leading OEMs and 9 major suppliers covering most sectors of the industry.

In particular, suppliers and OEMs were asked for their responses to the emergence of the supplier hub. The OEMs were asked:

- Do you use supplier hubs at present?

- What types of components are supplied through the hub?

- Will hubs affect Scottish suppliers?

- Will hubs be a long term or short term option?

- Will the emergence of hubs prove dangerous to the location of OEMs in Scotland?

- Do you expect to see a widening of the use of supplier hubs?

The suppliers were asked:

- Do you see supplier hubs as a threat to your business?

- Have you lost business due to the arrival of a hub?

- Will hubs prove dangerous to the location of OEMs in Scotland?

- Do you expect to see a widening of the use of supplier hubs? 


\section{REACTIONS TO THE EMERGENCE OF SUPPLIER HUBS}

Tables 1 and 2 give the results of the study. It was found that all the OEMs either presently use a hub or are considering developing the use of a hub. Company B is actively considering the use of a hub for both its Scottish built and imported products. It intends to bring five or six of its closest local suppliers into a hub to control inventory supply as well as imports. Most of the OEMs want to use a hub only for imported components. They are interested in the use of the hub to delay ownership of the goods until really required by production. Only company $\mathrm{C}$ gave space for inventory as a reason for the use of a hub.

The majority of firms do not regard the hubs as a threat to Scottish supplier companies at present. That the hubs could cause danger to the location of OEMs in Scotland was felt to be a possibility by only three companies. Two of the companies felt that the hub was a threat to their business - one had actually lost business to a hub - though they all thought that this method of supply would widen.

Most of the supplier companies believe that the hubs will not affect their industry sector and that their location, flexibility and ability to provide JIT supply would ensure their retention as a supplier to the OEMs.

Table 1 OEMs' reactions to emergence of supplier hubs

\begin{tabular}{lllll}
\hline Company & A & B & C & D \\
\hline Product & $\begin{array}{l}\text { Notebooks, } \\
\text { PC, Servers }\end{array}$ & $\begin{array}{l}\text { Test } \\
\text { equipment } \\
\text { and total } \\
\text { solution } \\
\text { (systems) }\end{array}$ & $\begin{array}{l}\text { Printers, fax } \\
\text { products, } \\
\text { consumables, } \\
\text { cellular phones }\end{array}$ & $\begin{array}{l}\text { Cash point } \\
\text { machines }\end{array}$ \\
\hline $\begin{array}{l}\text { Presently } \\
\text { Using? }\end{array}$ & $\begin{array}{l}\text { Using at } \\
\text { present }\end{array}$ & Yes & No, considering & $\begin{array}{l}\text { No, } \\
\text { considering }\end{array}$ \\
\hline $\begin{array}{l}\text { What types } \\
\text { of } \\
\text { component? }\end{array}$ & $\begin{array}{l}\text { Imported } \\
\text { products }\end{array}$ & $\begin{array}{l}\text { Scottish }+ \\
\text { imports }\end{array}$ & $\begin{array}{l}\text { Imports } \\
\text { (electronic } \\
\text { components, } \\
\text { power supplies) }\end{array}$ & $\begin{array}{l}\text { Overseas } \\
\text { imports }\end{array}$ \\
\hline $\begin{array}{l}\text { Affect } \\
\text { Scottish } \\
\text { suppliers? }\end{array}$ & No & $\begin{array}{l}\text { Yes - may } \\
\text { invite } 5 \text { or } 6\end{array}$ & No & No \\
\hline $\begin{array}{l}\text { Short/long } \\
\text { term option? }\end{array}$ & Long & Long & Long & Long \\
\hline $\begin{array}{l}\text { Dangerous to } \\
\text { location of } \\
\text { OEMs in } \\
\text { Scotland? }\end{array}$ & Potentially & No & No & No \\
\hline $\begin{array}{l}\text { Method } \\
\text { widening? }\end{array}$ & Yes & & & \\
\hline
\end{tabular}


Table 2 Supplier company reactions to emergence of supplier hubs

\begin{tabular}{llllll}
\hline $\begin{array}{l}\text { Com- } \\
\text { pany }\end{array}$ & Product & $\begin{array}{l}\text { Threat } \\
\text { to } \\
\text { business } \\
\boldsymbol{?}\end{array}$ & $\begin{array}{l}\text { Lost } \\
\text { business } \\
\text { to hub? }\end{array}$ & $\begin{array}{l}\text { Dangerous } \\
\text { to location } \\
\text { of OEMs in } \\
\text { Scotland? }\end{array}$ & $\begin{array}{l}\text { Method of } \\
\text { supply } \\
\text { widening? }\end{array}$ \\
\hline E & $\begin{array}{l}\text { Precision plastic } \\
\text { components }\end{array}$ & $\begin{array}{l}\text { Yes, } \\
\text { potential }\end{array}$ & No & Yes & Yes \\
\hline F & $\begin{array}{l}\text { PCBA } \\
\text { Assembly, Low } \\
\text { level assembly }\end{array}$ & No & No & No & $\begin{array}{l}\text { Yes, not in } \\
\text { PCBA }\end{array}$ \\
\hline G & $\begin{array}{l}\text { Cables, PCBA, } \\
\text { electronic } \\
\text { assembly }\end{array}$ & No & No & No & Potential \\
\hline H & PBCA & No & No & No & $\begin{array}{l}\text { Yes, not in } \\
\text { PCBA }\end{array}$ \\
\hline I & $\begin{array}{l}\text { Sheet metal, low } \\
\text { level assembly }\end{array}$ & No & No & No & Yes \\
\hline J & $\begin{array}{l}\text { Printed material, } \\
\text { product } \\
\text { identification }\end{array}$ & No & No & No & $\begin{array}{l}\text { Yes, not in } \\
\text { printed } \\
\text { material }\end{array}$ \\
\hline $\mathrm{K}$ & Cable goods & Yes - & Yes & $\begin{array}{l}\text { Yes (and } \\
\text { suppliers) }\end{array}$ & Yes \\
\hline L & PCBs & No & No & No & $\begin{array}{l}\text { Off shelf } \\
\text { components } \\
\text { only }\end{array}$ \\
\hline $\mathrm{M}$ & Keyboards & No & No & No & Yes \\
\hline
\end{tabular}

\section{CONCLUSIONS}

The electronics industry is the major manufacturing industry in Scotland. It comprises a large number of multi-national OEMs and a substantial supply base of large and small firms. As the competitive environment has changed over the past decades the industry, and economic planners, have had to tackle a variety of changing issues of technology management. Many threats to the future scale and wealth of the industry have emerged, with recently the emergence of supplier hubs. These involve a change of supply chain management strategy and may be seen as a challenge to the ability of local suppliers to secure a share of the OEMs' global spends.

A survey was carried out which seems to suggest that OEMs are all moving in the direction of supplier hubs, but at present suppliers do not consider this a serious 
threat to their operations. This may be due to a time lag in their awareness of the issues rather than a true picture.

\section{REFERENCES}

Scottish Enterprise, (1997) Electronics OEM Spend Analysis 1996, Scottish Enterprise, Glasgow.

Reid, A.E. (1998) An Investigation into Supplier Links in the Scottish Electronics Industry, Final Year project dissertation, University of Strathclyde, Glasgow.

\section{ACKNOWLEDGEMENT}

The authors acknowledge advice and information given by Ian Rodgers, Business Development Manager of SPEED (the Scottish Supply-chain Empowering Economic Development) and John Mearns of Scottish Enterprise.

\section{BIOGRAPHY}

\section{Allan Carrie}

Allan Carrie is Professor of Manufacturing Systems in the Department of Design, Manufacture and Engineering Management at the University of Strathclyde. He is a Chartered Engineer, Fellow of the IEE and of the RSA, a Senior Member of IEEE and a Member of IOM. He has industrial experience as an Industrial Engineer with Babcock and Wilcox in UK and with Northern Electric Ltd in Montreal, Canada. He is the author of a book on Simulation of Manufacturing Systems and over 130 papers. He served as a member of the Panel on Manufacturing, Production and Business Processes of the UK Technology Foresight Programme between 1994 and 1997. His main research interests are in computer aided production management and management of technology.

\footnotetext{
Alison Reid

Alison Reid is a final year student in the course leading to the Master of Engineering in Manufacturing Sciences and Engineering at the University of Strathclyde.
} 